\title{
Thai dogs carry bird-flu virus, but will they spread it?
}

Large numbers of domestic dogs and cats in Thailand may be infected with the H5N1 strain of avian flu, Nature has leamed. Experts arestruggling to work out whether such carnivores might be spreading the disease.

In an unpublished study carried out last year by the National Institute of Animal Health in Bangkok, researchers led by virologist Sudarat Damrongwatanapokin tested 629 village dogs and 111 cats in the Suphan Buri district of central Thailand. Out of these, 160 dogs and 8 cats had antibodies to $\mathrm{H} 5 \mathrm{N1}$, indicating that they were infected with the virus or had been infected in the past. "That's a lot," says Albert Osterhaus, a virologist at the Erasmus University in Rotterdam, the Netherlands. "This is definitely something to lookinto." So far, researchers at Bangkok's Chulalongkorn University have isolated the virus from at least one of the dogs.

Wild cats, including tigers, are known to be susceptible to the virus, but this is the first scientific study to find it in dogs, suggesting that infection could be widespread. Osterhaus is pressing officials at the UN Food and Agricultural Organization (FAO) and the World Organisation for Animal Health to monitor dogs, cats and other camivores for $\mathrm{H} 5 \mathrm{N1}$. "It's a gap inour surveillance," he says. "Basically all carnivores seem susceptible."

This study is the first to look at the prevalence of the virus in dogs or cats in the field despite anecdotal reports of cat deaths near poultry outbreaks. But Osterhaus's team has done experiments showing that domestic cats get ill and diefrom $\mathrm{H} 5 \mathrm{N1}$, and can transmit the disease to other cats (T. Kuiken et al. Soience 306, 241; 2004).

And lastmonth, a team from his lab published experiments showing that infected cats excrete virus in their faeces as well as in coughed-out droplets, suggesting that they could spread the disease

(G. F. Rimmelzwaan et al. Am. J. Pathol. 168, 176-183; 2006).

"It is still uncertain what role, if any, this might play in transmission," says Maria Cheng, a spokeswoman for the World Health Organization.

"Wedo nothave a full understanding of the viralload needed for human infection, and whether or not the infection of animals other than poultry might contribute."

JuanLubroth, a senior FAO animal-health officer, says that poultry - not cats and dogs is the priority for the agency, whose mandate is food security and agricultural livestock issues. The FAO "has only limited resources", he says.

As there is no evidence of dogs becoming ill or spreading H5N1, Lubroth believes the risk they pose is low. "It may be important, but today I am not able to cover all bases. Tomorrow I could be criticized for being wrong I will have to accept that responsibility." Declan Butler
ON THE RECORD

"It makes me mad that I could have had hot fudge sundaes all these years."

A Califomia woman who has been on a low-fat diet for 30 years responds to a major study revealing that such diets do not reduce the risk of cancer or heart disease.

"It's really sad the girls are winning. This isn't the game they should be winning at."

A paediatrician is dismayed by statistics showing that more US teenage girls than boys are smoking and abusing prescription drugs.

Sources: San Francisco Chronide, Washing ton Post

\section{SCORECARD}

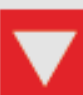
Science 'journalism' Petroleum geologists give author Michael Crichton a jour nalism award for his novel State of Fear, which dismisses the threat of global warming as an unrealistic scenario overhyped by wayward scientists.

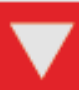
Nuclear waste ANevada family is threatened after their daughter, a contestant in this year's Miss America pageant, made comments in favour of a planned nuclear-waste repository at Yucca Mountain.

\section{NUMBER CRUNCH}

Even as Japan plans to significantly increase the number of whales it kills for scientific research, the Japanese are turning up their noses at the pungent, chewy meat. The government sells on carcasses for public consumption, but noone seems to be wildly enthusiastic.

$65 \%$ more whale meat reached the market in 2005, compared with a decade earlier.

$60 \%$ more minke whales will be killed this year compared with last year under govemment targets.

$30 \%$ was the dropin the price of whale meat between 1999 and 2004.

Source: Associated Press 